\title{
自己き裂治癒能力の応用によるセラミックスの接触強度向上*
}

$$
\begin{array}{llllll}
\text { 高 橋 } & \text { 啓 } & A^{* 1}, & \text { 西 尾 嘉 } & \text { 唯*2 } \\
\text { 高 橋 宏 } & \text { 治*3, 安 藤 } & \text { 柱*3 }
\end{array}
$$

\section{Improvement of Contact Strength in Ceramics by Crack-Healing}

\author{
Keita TAKAHASHI*4, Yoshitada NISHIO, \\ Koji TAKAHASHI and Kotoji ANDO \\ ${ }^{* 4}$ Graduate School of Engineering, Yokohama National University, \\ 79-5 Tokiwadai, Hodogaya-ku, Yokohama-shi, Kanagawa, 240-8501 Japan
}

\begin{abstract}
Ceramics are expected as the structural materials but they are brittle materials. Therefore there is a possibility of rapid fracture when a contact stress intensively acts on the surface of materials. Therefore improvement of reliability is needed for ceramics used under a local contact stress. In response, the crack healing ability of ceramics is extremely effective. If the crack-healing ability of ceramics is used on structural components, great benefits can be anticipated, such as an increase in the reliability of structural ceramic members and a decrease in the inspection, machining and polishing costs of ceramic components. In the present study, the effects of the crack-healing on contact strength were investigated for $\mathrm{Si}_{3} \mathrm{~N}_{4} / \mathrm{SiC}$ which was subjected to various machining process. The evaluation of contact strength was done by sphere indentation test that used acoustic emission (AE) together. As a result, the contact strength of $\mathrm{Si}_{3} \mathrm{~N}_{4} / \mathrm{SiC}$ was improved by crack-healing with a combination of rapping even for the material that had machining cracks induced by a heavily machining process.
\end{abstract}

Key Words : Ceramics, $\mathrm{Si}_{3} \mathrm{~N}_{4} / \mathrm{SiC}$, Crack-Healing, Contact Strength, Sphere Indentation

\section{1. 粕 言}

セラミックスは，耐摩耗性・耐食性に優れているこ とから，ベアリングなどの摺動部材として用いられて いる. また, 耐熱性に優れるため, ガスタービンなど の高温構造用部材としても期待されている. しかし, セラミックスは脆性材料であるため, 破壊勒性值が低 いという久点を持っている. 特に, 接触領域において は応力が集中的に作用するため, き裂が発生すると急 速破断に至る危険性を有している. そのため, 局所的 な接触応力下にお汸る信頼性向上に対する要望が高い. これまでの安藤らの研究(1)-(2)により，セラミックスが 有する自己き裂治痹能力を活用することにより，セラ ミックスの曲げ強度や疲労強度を大幅に向上できるこ とが明らかとなっている. 機械加工によって導入され る加工き裂, 及び使用中に発生するき裂を治症出来れ ば，構造用セラミックスの接触強度向上と，信頼性確 保の両方が達成できるであろう．また，加工き裂の治 痛は，セラミックス部材の製造コスト削減にもつなが る(3). 本研究では, セラミックスの接触強度特性に対

* 原稿受付 2010 年 5 月 6 日.

*1 学生員, 横浜国立大学大学院工学府(苾240-8501 横浜市保 土々谷区常盤台 79-5).

*2 横浜国立大学大学院工学府.

*3 正員, 横浜国立大学大学院工学研究院.

E-mail : ktaka@ynu.ac.jp
する自己き裂治㾑の効果を明らかにすることを目的と した. そのために, 接触強度に対するき裂治瘉効果を, アコースティック・エミッション（AE）を併用した球 圧子押込み試験によって評価した。

\section{2. 供試材及び実㰸方法}

2.1 供試材, 加工研磨処理方法 供試材は, $\mathrm{Si}_{3} \mathrm{~N}_{4}$ に $\mathrm{SiC}$ 粒子を $20 \mathrm{wt} . \%$ 複合した $\mathrm{Si}_{3} \mathrm{~N}_{4} / \mathrm{SiC}$ 複合材である. 焼結助剤として $\mathrm{Y}_{2} \mathrm{O}_{3}$ を $8 \mathrm{wt}$ \%用いて加圧燒結し，寸法

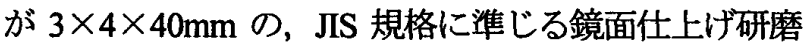
を行った試験片を作製した.これを「平滑材」と呼ぶ. 本研究では様々な表面状態での接触強度に対するき裂 治㾑効果を調査するために，平滑材に対して，種々の 表面加工を施した。 \#200 砥石による粗研磨相当の

「200 加工材」，\#400 砥石による中仕上げ研磨相当の 「\#400 加工材」，さらに，表面粗さの影響を考慮する ために, \#400 加工材の最表面の約 $5 \mu \mathrm{m}$ のみ粒径 $6 \mu \mathrm{m}$ のダイヤモンドスラリーでラッピング加工し，表面粗 さを抑えた「H400RAP材」を作製した. そして，それ らの試験片に対して，大気中で $1300^{\circ} \mathrm{C} ， 1$ 時間の熱処 理を施し，各試験片の接触強度に対する自己き裂治瘜 効果を検討した. 


\section{2 実験方法 表面の接触強度は, $\mathrm{AE}$ を併用} した球圧子押込み試験により評価した. 球圧子は WC 球 $(\phi 4.0 \mathrm{~mm})$ を用い，押込み負荷速度は $2.0 \mathrm{kN} / \mathrm{min}$ とし た. き裂発生により放出される AE 信号が, データレ コーダ上で検出された時の荷重をき裂発生限界荷重 $P_{\text {max }}$ とした. 試験力は荷重が $P_{\text {max }}$ に達した後, 直ちに 除荷した. 図 1 に球圧子押込み試験の概略図と $\mathrm{AE}$ 信 号を示した. き裂発生限界荷重は, Weibull 分布で表わ し，その尺度母数 $\beta$ （63\%破壊確率強度）を接触強度と 定義して評価した. その際，サンプル数は 15，ランク 法はメディアンランク法を用いた. また, 三点曲げ試 験による曲げ強度と触針式表面粗さ計による表面粗さ の測定も行った.

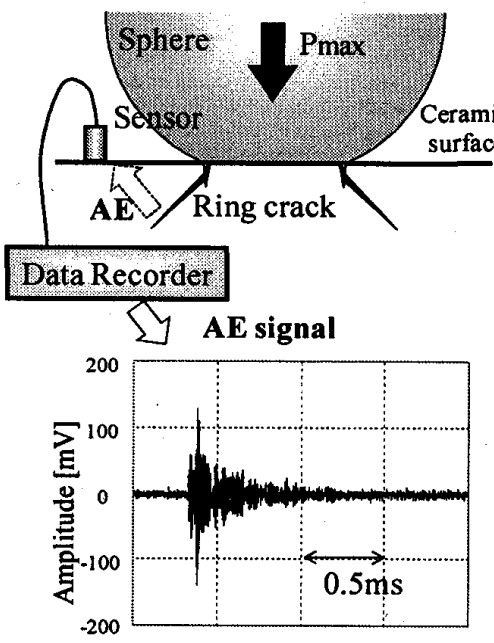

Fig. 1 Schematic illustration of ring-cracks on surface and $\mathrm{AE}$ signal

\section{3. 結果及び考察}

3.1 接触強度の Weibul 分布 表 1 に各試験 片の形状母数, 尺度母数, 曲げ強度及び表面粗さの值 を, 図 2 に, 各試験片の接触強度の Weibull 分布を示 した.

平滑材(O印)は，尺度母数付近より右上のプロット は，ばらつきが少なく，高い荷重域に集まり，左下の プロットは，ばらつきが大きく低い荷重域に表れてい る.これは，き裂の発生が，母材の強度だけでなく， 既存のき裂の有無にも依存するためと考えられる，つ まり，前者は，母材からのき裂発生を表し，後者は， 既存き裂からの新たなき裂発生を表していると考えら れる. 一方，この平滑材を治痹した平滑治癒材(○印) は，平滑材(○印)に比べて形状母数と尺度母数が大幅 に向上した.これは，加工き裂が治㾍されたため，鏡 面に残存する既存き裂からのき裂発生が少なくなった ためと考えられる.
Tablel Shape parameter $\alpha$ and scale parameter $\beta$ and bending strength and roughness of specimens

\begin{tabular}{ccccc}
\hline Specimens & $\begin{array}{c}\text { Shape } \\
\text { parameter } \\
\alpha[-]\end{array}$ & $\begin{array}{c}\text { Scale } \\
\text { parameter } \\
\beta[\mathrm{kN}]\end{array}$ & $\begin{array}{c}\text { Bending } \\
\text { strength } \\
\sigma[\mathrm{MPa}]\end{array}$ & $\begin{array}{c}\text { Surface } \\
\text { roughness } \\
R z[\mu \mathrm{m}]\end{array}$ \\
\hline Smooth & 1.9 & 0.65 & 861.9 & 0.10 \\
\hline $\begin{array}{c}\text { Smooth- } \\
\text { Healed }\end{array}$ & 3.8 & 0.93 & 915.4 & 0.66 \\
\hline \#200 & 1.4 & 0.33 & 521.6 & 2.74 \\
\hline $\begin{array}{c}\text { \#200- } \\
\text { Healed }\end{array}$ & 1.4 & 0.12 & 900.0 & 2.81 \\
\hline \#400 & 1.4 & 0.40 & 648.5 & 1.52 \\
\hline $\begin{array}{c}\text { \#400- } \\
\text { Healed }\end{array}$ & 1.1 & 0.30 & 913.7 & 1.82 \\
\hline $\begin{array}{c}\# 400- \\
\text { RAP }\end{array}$ & 1.1 & 0.56 & 676.2 & 0.15 \\
\hline $\begin{array}{c}\text { \#400-RAP- } \\
\text { Healed }\end{array}$ & 3.6 & 1.06 & 856.5 & 1.02 \\
\hline $\begin{array}{c}\text { \#400- } \\
\text { Healed-RAP }\end{array}$ & 3.2 & 1.06 & - & 0.23 \\
\hline & & & & \\
\hline
\end{tabular}

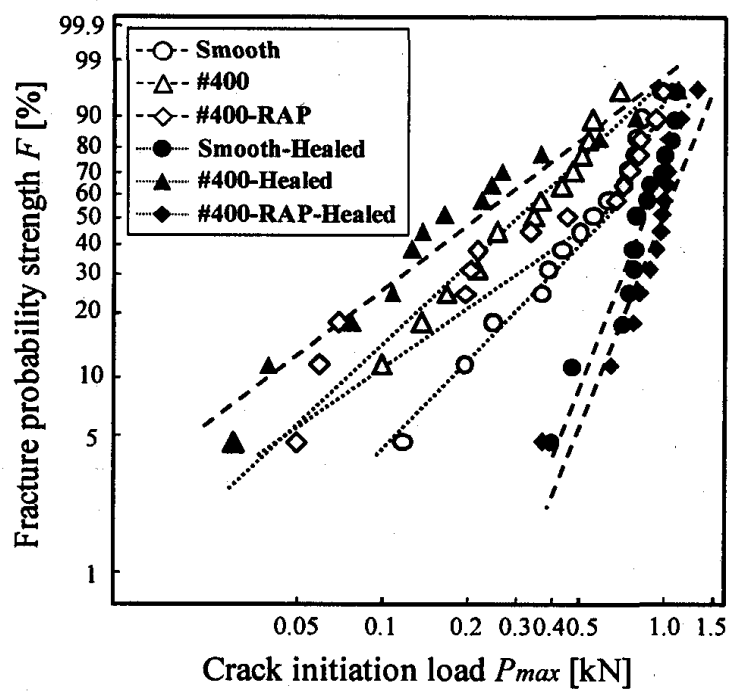

Fig.2 Weibull distribution of crack initiation load

図 2 に示したように, \#400 加工材( $\triangle$ 印)では, 形状 母数，尺度母数ともに，平滑材より低い值を示した. これは，加工による既存き裂が多数存在するため，き 裂発生要因の大半が既存き裂によるものであったため と考えられる. また, \#400 加工材を治瘉した 4400 加工 治癐材( $\Delta$ 印)の尺度母数は\#400 加工材よりも低い值と なった. その原因として，加工き裂は治痹されたが; 加工による表面粗さが大きいため，表面の凹凸を治瘉 物質により完全に埋めることが出来なかったことが考

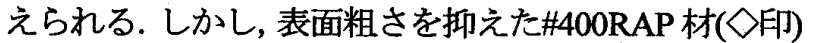
は低荷重域を除き平滑材と同様の接触強度分布を示し た. 一方, \#400RAP 治瘉材(け印)は平滑治㾑材と同様 の強度分布を示した. よって，接触強度は，き裂発生 要因となる既存き裂を治庩することによって向上する 
ことがわかった．また，強加工が施された部材は，接 触強度が低く，治痊しても接触強度は上がらないが， 表面層のみのラッピングを行い，表面粗さを抑えた後 に治瘉することで，接触強度が大幅に向上することが わかった。

\section{3 -2 表面粗さが曲け強度に及ぼす影辢 図 3 に} 表面粗さと曲け強度の関係を示寸. 図 3 より, 治瘜し ていない試験片は，加工条件が峳しいものほど粗さは 大きくなり，曲げ強度は低くなった。 しかし，これら は，き裂治癒を施すことによって全ての試験片におい て，平滑材と同等またはそれ以上まで曲げ強度が向上 した. よって，表面粗さによらず，全ての試験片にお いて，既存き裂は完全に治㾑されたと考えられる. ${ }^{(3)}$

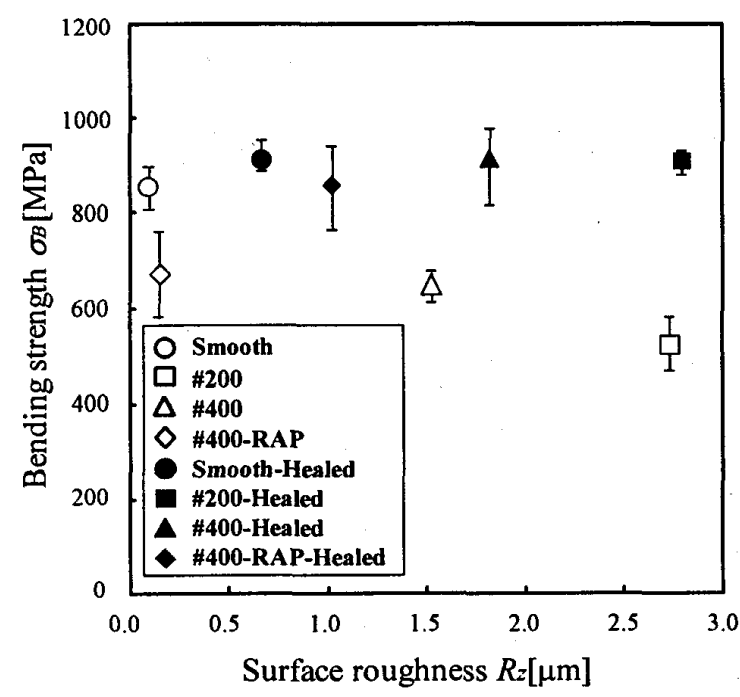

Fig.3 Relationship between bending strength and surface roughness of specimens

\section{3 -3 表面粗さが接触強度に及ぼす影得 図 4 に} 表面粗さと接触強度の関係を示す，この際，接触強度 は図 2 及び表 1 における尺度母数及の值にて評価した. 図 4 に示すように，接触強度においては，治㾑前の試 験片は, 表面粗さの増加に伴い, 強度が低下した. ま た, 平滑治癒材と $\# 400 R A P$ 治㾑材は, 治癒により, 既 存き裂が完全に治㾍されたため, 接触強度が大幅に向 上した. しかし, $\# 400$ 加工治瘉材と $\# 200$ 加工治癒材は, 既存き裂が完全に治瘑されているにも関わらず，接触 強度は向上しなかった，よって，接触強度は，既存き 裂だけでなく部材の表面粗さにも大きく依存すると考 えられる、そこで, 表面粗さが大きいために接触強度 が低くなったと考えられる\#400 加工治瘉材に対して, 最表面のみ $5 \mu \mathrm{m}$ 程度ラッピング研磨し, 粗さを抑えて 接触強度を測定したところ，図中印で示すように， 大幅な接触強度向上が得られた。 このことから，接触
強度は，自己き裂治㾑により既存き裂を治癒し，さら に表面粗さを抑えることで大幅に向上させることが出 来ることがわかった.

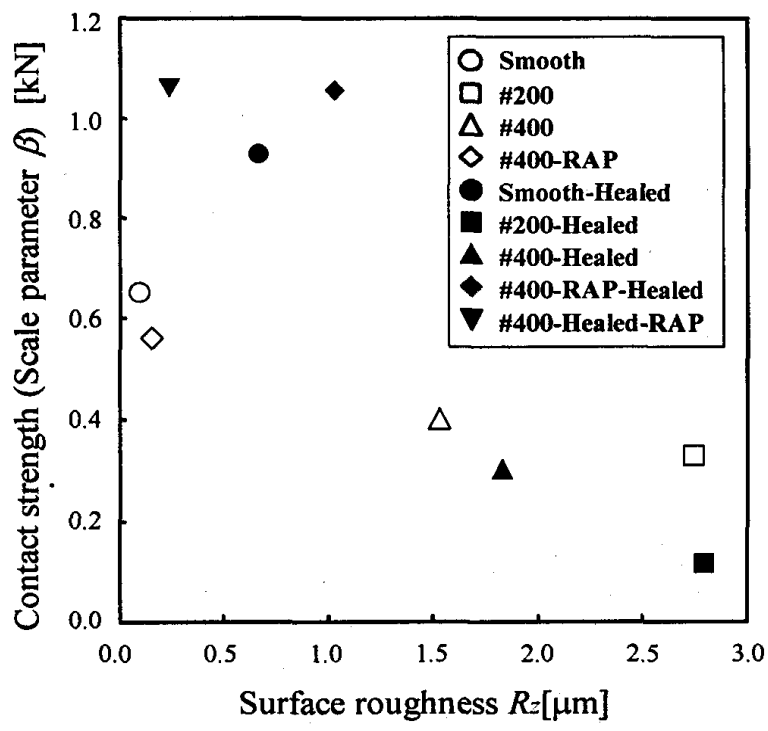

Fig.4 Relationship between contact strength and surface roughness of specimens

\section{4. 結竞}

製造工程における高効率な加工によって，き裂が多 く生じても, き裂治瘉の前後のいずれかに最表面の粗 さのみ取り除けば，窒化ケイ素／炭化ケイ素複合材の 接触強度は大幅に向上するという新しい知見が得られ た.この結果は，セラミックス部材の製造コスト削减 や，信頼性向上に大きく貢献できるものであると言え る.

謝辞

本研究は科研費若手研究 B(課題番号:20760067)の支 援により実施された.ここに記して謝意を表します

\section{文献}

(1) Ando,K.,Chu,M.,Kobayashi,Y.,Yao,F.,Sato,S.,Cra ck Healing Behavior and High Temperature Strength of Silicon Nitride Ceramics, Transactions of the Japan Society of Mechanical Engineers A,vol.65,633(1999-5),pp.1132-1139

(2) Yao,F.,Ando,K.,Chu,M.,Sato,S., Static and Cyclic Fatigue Behavior of Crack-Healed $\mathrm{Si}_{3} \mathrm{~N}_{4} / \mathrm{SiC}$ Composite Ceramics, Journal of the European Ceramics Society vol.21(2001), pp.991-997

(3) Jung,Y.,Nakao,W.,Takahashi,K.,Ando,K.,Saito,S., Strength Recovery of Heavily Machined $\mathrm{Si}_{3} \mathrm{~N}_{4} / \mathrm{SiC}$ Composite Ceramics by Crack-Healing, Transactions of the Japan Society of Spring Engineers vol.52(2007),pp.98-102 